Atouts et outils de l'ethnologie des techniques

\title{
Des schèmes culturels dans l'observation et la construction d'objets
}

Marie-Noëlle Chamoux

\section{(2) OpenEdition}

12 Journals

Édition électronique

URL : https://journals.openedition.org/tc/617

DOI : $10.4000 /$ tc. 617

ISSN : 1952-420X

Éditeur

Éditions de l'EHESS

Édition imprimée

Date de publication : 1 septembre 1994

ISSN : 0248-6016

Référence électronique

Marie-Noëlle Chamoux, «Des schèmes culturels dans l'observation et la construction d'objets »,

Techniques \& Culture [En ligne], 21 | 1994, mis en ligne le 30 décembre 2005, consulté le 29 septembre 2022. URL : http://journals.openedition.org/tc/617 ; DOI : https://doi.org/10.4000/tc.617

Ce document a été généré automatiquement le 29 septembre 2022

Tous droits réservés 
Des schèmes culturels dans

l'observation et la construction

d'objets

Marie-Noëlle Chamoux 